\title{
Slope Stability and Slope Formation in the Flysch Zone of the Vienna Forest (Austria)
}

\author{
Birgit Terhorst $^{1}$ and Bodo Damm ${ }^{2}$ \\ ${ }^{1}$ Institute of Geography, University of Würzburg, 97074 Würzburg, Germany \\ ${ }^{2}$ Institute of Geography, University of Regensburg, 93053 Regensburg, Germany \\ Correspondence should be addressed to Birgit Terhorst, birgit.terhorst@uni-wuerzburg.de
}

Received 17 July 2008; Revised 19 January 2009; Accepted 10 March 2009

Recommended by Atle Nesje

The Rhenodanubian Flysch of the northern Vienna Forest is composed of various layers of sandstones, marly shales, calcareous marls, and clay shists, which are covered by Quaternary periglacial cover beds and loess deposits. This area at the margin of the eastern Alps represents an undulating landscape of the Austrian low-mountain regions. The Vienna Forest Flysch region is considered to be susceptible to landslides. Both petrography of the bedrock and soil mechanical properties of the Quaternary sediments control the current slope dynamics in the study area. In a temporal context it is evident that the stability of slopes exceeding $27^{\circ}$ is controlled by a succession of several steps of slope formation. On the basis of field surveys, laboratory analyses, and slope stability modelling, results from investigations on recent landslides demonstrate five different phases of slope formation. In general, after passing these phases the stability of studied slopes is increased, due to the different soil mechanical properties of the potential sliding masses.

Copyright (C) 2009 B. Terhorst and B. Damm. This is an open access article distributed under the Creative Commons Attribution License, which permits unrestricted use, distribution, and reproduction in any medium, provided the original work is properly cited.

\section{Introduction}

Human living and managing takes places in a space, which is influenced mainly by Quaternary sediments and forms. They affect present day geomorphological and hazardous processes. To predict future developments, also concerning landuse and planning management, it is essential to know the past processes that led to recent conditions. Furthermore, the reconstruction of former landscapes and ecosystems is a prerequisite to evaluate and to measure anthropogenic modifications in space and time. Models of landscape formation contribute substantially to the comprehension of geosystems and their comparability.

In order to recognise and evaluate the controlling factors of actual morphodynamic processes, the retrospective analysis exhibits a significant relevance [1-3]. However, numerous studies predominantly incorporate short and more recent geological periods comprising a few decades. Furthermore, they hardly reach back prior to the beginning of the modern age due to methodological reasons.
On the other hand, it seems to be essential to involve additional changes in weathering processes, sediment budgets, topography, and other fundamental process parameters for longer periods of the Quaternary [4-11]. It is evident that the spatiotemporal susceptibility of morphodynamic processes depends on a long-term development of the mentioned parameters (cf. $[12,13])$.

Thus, in studying natural hazards as a core field of applied geomorphology, the chronological aspect plays an essential role for the assessment of hazards [14-18].

However, datable material is rarely available but chronostratigraphical classification can also be done by analysing the development of soils Miller et al. [19] and the distribution of periglacial cover beds $[6,20,21]$. To differentiate Pleistocene and Holocene slope formation, the model of periglacial cover beds was applied in the study area, which is valid for the Central European region [22]. Furthermore, the local occurrence of loess in the study area allows to establish minimum ages for the formation of Pleistocene slopes.

The prominence of Quaternary landscape evolution and morphodynamics for applied geomorphology has only been 
investigated in a few papers (cf. van Husen [23]). However, the linkage of demands concerning Quaternary landscape formation with such of applied geomorphology constitutes a considerable approach in the field of system analyses. The present study focuses on this interface.

1.1. Periglacial Cover Beds as Stratigraphic Tool. In Central European low-mountain regions studies on disconformities in soil parent material are numerous. The disconformities are caused by periglacial Pleistocene processes, mainly by solifluction and/or solimixtion processes in the former active layer, on top of the former permafrost level [24]. Periglacial phenomena occur in form of ice-wedges, cryoturbation structures, wavy boundaries, clasts that concentrate between the boundaries of the layers, high bulk density, and an admixture of loess. Periglacial layers are widespread in lowmountain areas and show systematic stratification, represented by a model developed by Semmel [20] and Schilling and Wiefel [25]. Three main units consisting of periglacial cover beds can be distinguished.

The underlying basal periglacial cover bed and, respectively, basal layer, according to [26], are composed of bedrock debris. During the formation phase, bedrock and its periglacial debris formed the surface, namely, before the onset of loess accumulation. It is, therefore, free of allochthonous material. Rock fragments are usually oriented parallel to the slope [26].

The middle periglacial cover bed (intermediate layer [26]) can superimpose the basal periglacial cover bed and is preserved in morphological positions, which have not been subject to periglacial erosion. In addition to material originating from bedrock, this layer contains loess. According to the AD-HOC-Arbeitsgruppe Boden [22] the intercalated clasts are diagnostic. In the case that the solifluction process reworked pure loess, a doubtless classification is difficult [27]. Therefore, in this study the middle periglacial cover bed and pure loess layers are combined in one unit as "loess." In general, most authors suppose a Late Glacial formation for this cover bed (e.g., $[6,28])$.

The youngest, upper periglacial cover bed occurs widespread and with a homogenous thickness of $30-70 \mathrm{~cm}$, thus reflecting the depth of the former active layer [24]. This cover bed is characterised by enhanced silt content in comparison to the underlying strata, which is due to loess deposition from the Late Glacial. Beside local minerals, minerals are present, which originate from a far distance transport. Furthermore, it consists of rock fragments.

In Central European areas, the upper periglacial cover bed constitutes a relative stratigraphic marker layer due to the occurrence of volcanic components. Characteristic for the latter are minerals of the Laacher See Tephra (LST), namely, brown amphibole, titanite, and clinopyroxene. The ashes of the Laacher vulcano are widespread in Central Europe and exhibit the described combination of minerals, thus being easily distinguished from other ashes. Since the eruption of the Laacher See volcano is dated to 12.900 years BP [29], it can be used as a chronostratigraphic marker for the formation age of the upper periglacial cover bed. After the deposition of volcanic minerals, the described aeolian and volcanic components were admixed with bedrock by solifluction or similar periglacial processes. The previous considerations yield the fact that the age of the last solifluction phase as recorded in the upper periglacial cover bed is definitely younger than 12.900 years BP. Beyond this date, there is only one period of periglacial conditions documented in Central Europe-the Younger Dryas, representing a time span between 12.700 and 11.600 years BP [30]. Consequently, the solifluidal formation of the upper Cover Bed can definitely be dated to the Younger Dryas $[6,27]$. This knowledge can be transferred to regions, where the upper periglacial cover bed can be identified, however, without presence of the LST minerals, like in the case of the Vienna Forest.

It should be stressed that some authors state that the formation of the upper periglacial layer is older than Younger Dryas and formed prior to the Alleroed [31]. At present stage of investigation the mentioned results can be considered as singular case. In this context some authors discuss the occurrence of two upper periglacial layers of different age (cf. [27]).

\section{Study Area}

The study area is situated in the northern Vienna Forest, close to the city of Vienna (Figure 1). This area represents an undulating landscape of the central European low-mountain regions with altitudes ranging between 300 and $500 \mathrm{~m}$ ASL. The flat mountains of the Vienna Forest are deeply incised by valleys, partly forming gorges with overly steep slopes. In general, small creeks flow through the valleys, which are affected by torrential dynamics.

The study area constitutes a part of the northern margin of the Alps and belongs to the Rhenodanubian Flysch Zone, which is orientated in W-E direction. It declines below the Vienna basin in the periphery of Vienna [32].

The Flysch zone of the Vienna Forest consists of various layers of (calcareous) sandstones, marly shales, calcareous marls, and clay shists (Figure 2). The formations of the study area belong predominantly to the Altlengbach and the Greifenstein beds. They are dominated by calcareous quartzitic sandstones, marls, and clays, which are covered by Quaternary periglacial cover beds and loess.

Concerning slope stability, Flysch regions are considered to be susceptible to landslides (Table 1, cf. $[33,34]$ ). Both petrography of the bedrock and soil mechanical properties of the Quaternary sediments control the actual slope dynamics in the Vienna Forest regions. In particular, calcareous sandstones tend to profound decomposition under influence of humidity "Mürbsandstein" as the carbonate cement can be removed quickly.

\section{Methodology}

The analysis of morphodynamic processes and their framework requires geomorphological and geological parameters as well as soil mechanical parameters simultaneously [35, 


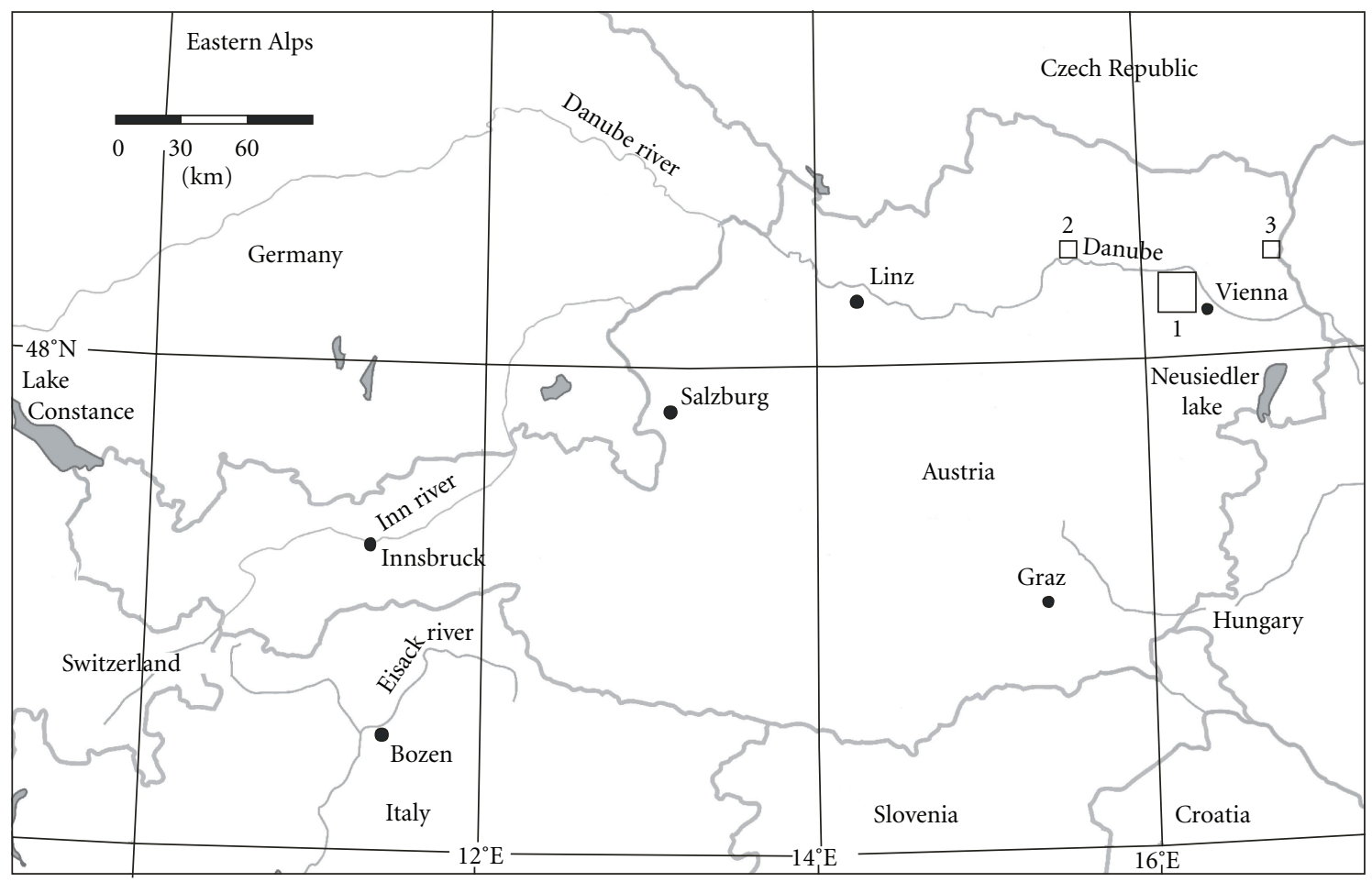

FIGURE 1: Location of the study area in the North-West of Vienna in the Vienna Forest.

TABle 1: Mass movement in the federal state of Lower Austria, as differentiated by various types of processes and geological units (values in percent). Since the 1960s, ca. 1200 events were observed (data source: [34]).

\begin{tabular}{|c|c|c|c|c|c|c|c|c|}
\hline Process & $\begin{array}{l}\text { Bohemian } \\
\text { massif }\end{array}$ & $\begin{array}{l}\text { Molasse belt/ } \\
\text { Tertiary basin }\end{array}$ & Flysch zone & Cliff zone & $\begin{array}{l}\text { Alpine } \\
\text { limestone } \\
\text { zone }\end{array}$ & $\begin{array}{l}\text { Greywacke } \\
\text { zone }\end{array}$ & Central zone & $\begin{array}{l}\text { Observed } \\
\text { damaging } \\
\text { events }\end{array}$ \\
\hline Landslide & 1,5 & 16 & 42 & 20 & 14 & 0,5 & 6 & 1.100 \\
\hline Debris flow & 8 & 5 & 20 & 5 & 50 & - & 12 & 80 \\
\hline Rockfall & 45 & - & 4,5 & - & 41,5 & - & 9 & 46 \\
\hline
\end{tabular}

36]. For this reason, the methodology of the presented study incorporates field mapping and surveying, soil and sediment analyses, drilling, shear strength measurements, soil mechanical laboratory analyses, and computer-aided slope stability calculation (i.e., [37-39]).

3.1. Soil Mechanical Properties. Soil mechanical properties have an important impact on movements and forces in soils directly related to slope stability. In addition to the physical properties of the coarse fraction $(>2000 \mu)$, those of the fine earth fraction $(<2000 \mu)$ are of significant relevance. In greater detail, grain size, grain structures, pore rates, water contents and permeability control essential shear strength parameters such as friction angle, cohesion, and deformability [40]. To a large extent, the soil physical analyses were processed according to the recommendations of the German National Standards Institute [39]. Stability relevant attributes of the substrates were derived from the laboratory data combined with equations using standard parameters according to DIN [41, 42]. Laboratory analyses include grain size determination (Köhn pipette, ÖNORM L 1061 and B4412 [43]).

3.2. Slope Stability Calculation. Slope stability analyses aim to evaluate the internal slope stability of natural slopes and embankments. As a matter of principle those calculations are based on empirical model approaches according to Terzaghi [44]. Later modifications are adapted from Knoblich [35], Gudehus et al. [37], and Gussmann [38]. All approaches consider different kinematics of slide processes. In general, the calculations are based on the fact that the sum of driving forces, $\mathrm{T}$, is related to the sum of resisting forces, $\mathrm{H}$. With respect to the resisting forces, $\mathrm{H}$, the shear strength has to be considered as the prominent parameter. The safety against failure of embankments is expressed by the safety factor, $\eta$, based on the equation

$$
\eta=\frac{H}{T}
$$



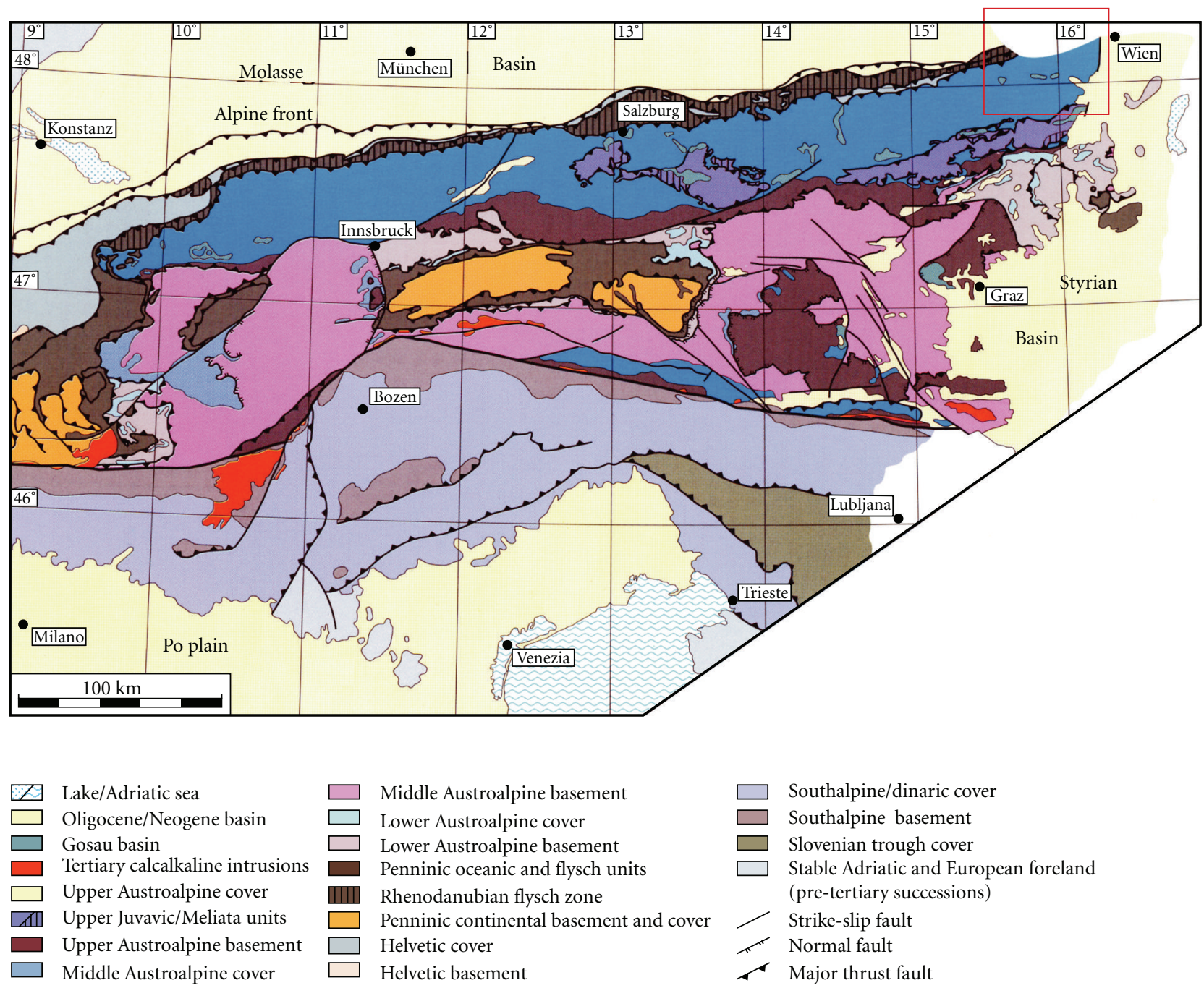

FIGURE 2: Geological map of the Eastern Alps and the position of the Vienna Forest Flysch zone (modified after Neubauer and Höck [32]).

The shear stress at the slip plane was determined in accordance with the Mohr-Coulomb failure criterion.

The landslides considered in the present study are described as "infinite mechanical slide model," where slope failure produce a shallow planar slide of great width and considerable length compared with the depth (cf. [37, 41]). Basically, this model is applied in soil complexes with a layering relevant for soil mechanical properties and thus, with a predetermined discontinuity. The analysis ignores possible lateral effects.

The resisting forces are the effective shear strength of the soil and the driving forces are the gravitational forces tending to move the soil down the hillslope, together with the tendency of water to reduce soil strength and to cause a bouyancy effect within the soil. Driving forces and resisting forces are described through the unit weight of soil $\left(F_{G}\right)$, the length of the sliding mass, respectively, sliding plane $(L)$, and through base variables (angle of friction $\varphi$, cohesion $c$, pore water pressure derived from the unit weight of water $u$, hydrostatic pressure $v$, angle of slope, resp., slide plane inclination $\alpha$ ). The mechanical model acquires driving and resisting forces as follows:

$$
\begin{aligned}
T & =F_{G} \cdot \sin \alpha+v\left[\mathrm{kN} / \mathrm{m}^{2}\right], \\
H & =\tan \varphi \cdot\left(F_{G} \cdot \cos \alpha-u\right)+c \cdot L\left[\mathrm{kN} / \mathrm{m}^{2}\right] .
\end{aligned}
$$

The unit weight of soil $F_{G}$ of the sliding mass is calculated according to

$$
F_{G}=\gamma_{B} \cdot L \cdot d\left[\mathrm{kN} / \mathrm{m}^{2}\right],
$$

where $\gamma B$ is the specific weight of the (moist) soil and $d$ is the vertical depth of the sliding mass. In the case that measured values are not available, pore water pressure $u$ and hydrostatic pressure $v$ are calculated. This procedure can be applied if there is an adequate knowledge on the formation of the slide mass and its basement.

The effective pore water pressure $u^{\prime}$ results from

$$
u^{\prime}=u \cdot L=\gamma_{w} \cdot h_{w} \cdot L\left[\mathrm{kN} / \mathrm{m}^{2}\right],
$$


where $\gamma_{w}$ is the specific weight of water and $h_{w}$ is the vertical height of the water table above the slide plane as a part of the soil thickness above the plane. The hydrostatic pressure $v$ is calculated in assumption of a slope parallel flow through

$$
v=L \cdot d \cdot \gamma_{w} \cdot I=L \cdot d \cdot \gamma_{w} \cdot \sin \alpha\left[\mathrm{kN} / \mathrm{m}^{3}\right],
$$

where the hydraulic inclination is $I=\sin \alpha$ (calculation according to $[35,44])$.

\section{Results}

4.1. Slope Surfaces and Sediments. The slopes of the Flysch zone are characterised by various types of sediments. Loess layers, periglacial cover beds, marls, and sandstones, partly decomposed, form the slope surface. In general, a completely developed, undisturbed profile is characterised by a sequence of different geological layers in the study area (Figure 3). The base of the sequence is mainly formed by Flysch sandstones, superimposed by periglacial cover beds, which consist of debris of clays and marls. These deposits are exclusively composed of bedrock debris and formed by solifluction processes during periglacial conditions and therefore they are densely bedded. As characteristic phenomena, stone fragments are orientated with their long axis in slope direction and cryoturbation structures in the form of small involution bags and wavy boundaries are developed. In the international and German nomenclature, this layer is named the basal cover bed [21]. A special emphasis should be placed on the fact that the described impermeable periglacial cover beds are responsible for the occurrence of springs [3].

The hanging layer consists of permeable calcareous loess deposits $(\leq 4 \mathrm{~m})$, which is supposed to be of the last glacial period (datings in process). The grain size fractions are dominated by silt, in particular coarse silt, and the loess has an overall loose consistence. The basal part of the loess shows hydromorphic features in the form of rusty iron bands alternating with greyish lines. This fact is due to the stagnant properties caused by the underlying basal cover bed. The top of the sequence is terminated by a further periglacial cover bed, composed of a mixture of loess and sandstones. This layer corresponds to the upper Periglacial layer and originates from the Younger Dryas (cf. [20, 21, 27, 45]).

The recent soil developed in loess dominated sediments and can be classified as Luvisol, consisting of EB and Bt horizons (Figure 3).

4.2. Sedimentology. Of special interest concerning the slope stability calculation is the composition of the loess layers. They are dominated by the silt fraction, which ranges between 55.5 and $62.0 \%$ (Table 2). Inside the silt fraction, coarse silt constitutes the most important part (41.0$48.0 \%$ ), whereas fine and middle silt contents are clearly reduced. The loess has minor clay contents with a maximum at $12.6 \%$. In general, the sand fraction is characterised by comparably enhanced values as the local bedrock are sandstones mainly. In particular, the fine sand contents are enhanced, whereas well developed loess profiles of the region

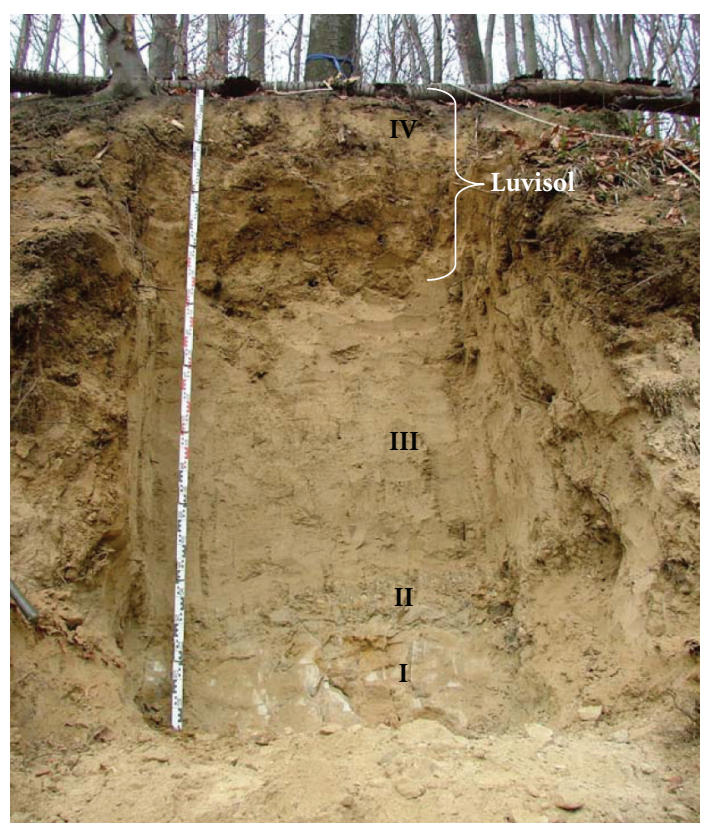

FIGURE 3: Initial situation: the profile illustrates the Flysch basement (I), the basal periglacial cover bed with marls, and sandstone debris (II), the loess deposit (III), as well as the Upper periglacial cover bed (IV).

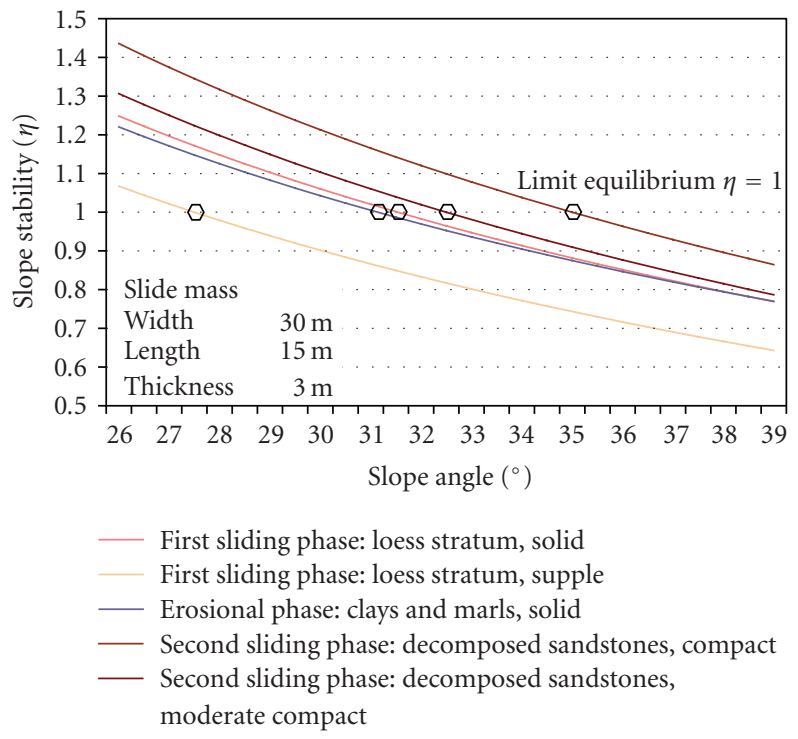

FIGURE 4: Slope stability calculation for a model landslide regarding slope angle and soil mechanical characteristics according to Table 3. After passing phases $1-5$, the stability of slopes is increased by $3-5^{\circ}$ on average.

have no significant sand fraction [46]. The impermeable basal cover bed shows an enhancement of clay (31.8\%) and has a bit less silt as described for the loess layers. Nevertheless, the silt content dominates the grain size with values between 53.8 and $59.0 \%$. However, the consistence and distribution inside the silt classes deviate from those of the loess. In the case of the periglacial basal cover bed, 
TABLE 2: Grain size analyses of characteristic sediments and soil horizons in the study area.

\begin{tabular}{|c|c|c|c|c|c|c|c|c|c|c|c|}
\hline \multirow[t]{3}{*}{ Profile } & \multirow[t]{3}{*}{ Horizon/layer } & \multirow[t]{3}{*}{ Texture } & \multirow{3}{*}{$\begin{array}{c}\text { Clay } \\
\mu \\
<2\end{array}$} & \multicolumn{4}{|c|}{ Silt } & \multicolumn{4}{|c|}{ Sand } \\
\hline & & & & Fine & Middle & Coarse & Total & Fine & Middle & Coarse & Total \\
\hline & & & & $2-6$ & $6-20$ & $20-63$ & & $63-200$ & $200-630$ & $630-2000$ & \\
\hline $1-1$ & $\begin{array}{l}\text { EB, Upper cover } \\
\text { bed }\end{array}$ & $1 \mathrm{U}$ & 19,0 & 6,3 & 15,6 & 40,4 & 62,2 & 16,4 & 1,5 & 0,3 & 18,8 \\
\hline $1-2$ & Bt1, soil & $\mathrm{uL}$ & 25,4 & 5,4 & 12,5 & 38,6 & 56,5 & 16,6 & 1,3 & 0,2 & 18,1 \\
\hline $1-3$ & Bt2, soil & $1 \mathrm{U}$ & 29,5 & 4,1 & 10,6 & 35,1 & 49,8 & 19,1 & 1,4 & 0,3 & 20,7 \\
\hline $1-4$ & $\mathrm{C} 1$, loess & $\mathrm{sU}$ & 6,8 & 3,4 & 9,0 & 43,1 & 55,5 & 33,8 & 3,2 & 0,8 & 37,7 \\
\hline $1-5$ & $\mathrm{C} 2$, loess & $\mathrm{sU}$ & 7,8 & 3,4 & 10,6 & 48,0 & 62,0 & 22,4 & 3,7 & 4,2 & 30,2 \\
\hline $1-6$ & C3, loess & $s \mathrm{U}$ & 7,4 & 4,0 & 10,1 & 45,5 & 59,5 & 30,0 & 2,3 & 0,9 & 33,1 \\
\hline $1-7$ & C4, Basal cover bed & $1 \mathrm{U}$ & 31,8 & 19,7 & 20,8 & 13,3 & 53,8 & 4,8 & 4,1 & 5,5 & 14,4 \\
\hline drilling & C, Flysch marls & $1 \mathrm{U}$ & 23,3 & 6,4 & 16,1 & 35,6 & 58,1 & 16,1 & 2,3 & 0,2 & 18,6 \\
\hline 2 & $\begin{array}{l}\text { C, decomposed } \\
\text { sandstone }\end{array}$ & 1S & 7,1 & 4,7 & 9,5 & 17,6 & 31,7 & 35,0 & 20,7 & 5,6 & 61,2 \\
\hline 3 & $\begin{array}{l}\text { C, decomposed } \\
\text { sandstone }\end{array}$ & IS & 10,5 & 4,9 & 9,9 & 14,5 & 29,3 & 28,8 & 18,1 & 13,3 & 60,2 \\
\hline 4 & $\begin{array}{l}\text { C, decomposed } \\
\text { sandstone }\end{array}$ & S & 3,0 & 1,8 & 5,3 & 10,3 & 17,4 & 36,0 & 42,3 & 1,4 & 79,6 \\
\hline 5 & $\begin{array}{l}\text { C, decomposed } \\
\text { sandstone }\end{array}$ & S & 4,0 & 2,6 & 6,3 & 11,1 & 19,9 & 31,6 & 39,9 & 4,6 & 76,1 \\
\hline 6 & $\begin{array}{l}\text { C, decomposed } \\
\text { sandstone }\end{array}$ & IS & 10,4 & 6,5 & 14,3 & 19,6 & 40,3 & 31,4 & 15,4 & 2,6 & 49,3 \\
\hline 7 & C, loess & $\mathrm{sU}$ & 8,8 & 4,9 & 9,9 & 41,0 & 55,9 & 31,7 & 2,5 & 1,2 & 35,3 \\
\hline 8 & C, loess & $\mathrm{sU}$ & 12,6 & 4,7 & 11,6 & 42,8 & 59,0 & 25,6 & 2,5 & 0,3 & 28,4 \\
\hline
\end{tabular}

the contents of fine, middle, and coarse silt are more or less similar. Here, the clay content with $31.8 \%$ shows a significant peak and together with the percentage of fine silt (19.7\%), more than $50 \%$ of the layer is formed by fine sediments (Table 2).

The samples that originate from decomposed sandstone are certainly dominated by the sand content, which lies between 49.3 and $79.7 \%$, and is two to three times higher than in the described loess and marls. The major contents are in the middle and fine sand fraction, whereas coarse parts are only of minor interest. Silt contents range between 17.4 and $40.3 \%$ with maxima in coarse silt.

\subsection{Soil Mechanical Stability Criteria}

4.3.1. Loess Sediments. The grain size of the low plastic loess silts was classified as "UL" for soil mechanical reasons. The bedding is designated as moderate dense (Ld 3). The insitu shear strength, which was measured under low field moisture, ranges between $50-85 \mathrm{kN} / \mathrm{m}^{2}$ (Table 3 ). As a result, it is possible to classify the loess sediments at a friction angle of $27.5^{\circ}$ and additionally considering cohesion under dry conditions, as stable up to a slope gradient of $40^{\circ}$ and more (Figure 4). Under the influence of adequate moistening, it can be stated that the transition from supple to solid conditions is related to an increasing loss of the cohesion. Thus, stability is reduced to the value of the friction angle (cf. [37]).
4.3.2. Clays and Marls of the Periglacial Cover Beds. On the base of grain size, the moderate plastic clays and marls as present in the basal periglacial cover beds are attributed to the soil mechanical class "TM." The bedding is predominantly dense, corresponding to the level "Ld 5." The span of the in-situ shear strength, which was measured under low field moisture, is between $85-190 \mathrm{kN} / \mathrm{m}^{2}$ (Table 3). The stability of the present periglacial cover beds is comparable to that of the loess sediments. They are stable under dry conditions up to a slope gradient of $45^{\circ}$ and more (Figure 4).

With increasing moistening and at the transition from solid to supple consistency, the strength of the periglacial clays and marls decreases fast. Thus, the soil mechanical stability is reduced to the friction angle in the case of supple conditions and at a total loss of cohesion (cf. [47, 48]).

4.3.3. Sand-Silt Aggregates of Decomposed Sandstones. The sand-silt mixture of the decomposed sandstones is, in turn, not cohesive and characterised by a moderate to strong carbonate content. The soil mechanical class was determined on the basis of the grain size as "SU." Depending on the density of bedding, different values of in-situ shear strength were measured under low field moisture. In the case of moderate dense bedding, the values range between 11 and $15 \mathrm{kN} / \mathrm{m}^{2}$ and the range for dense bedding is between 20 and $45 \mathrm{kN} / \mathrm{m}^{2}$ (Table 3 ). The compactness of sand-silt aggregates is determined by the bedding density of sediment particles 
TABLE 3: Soil mechanical characteristics and shear strength values of the mantle rocks and loam beds of landslide areas in the Vienna Forest Flysch zone, based on laboratory analyses, as well as in situ measurements.

\begin{tabular}{|c|c|c|c|c|c|c|}
\hline Soil type & $\begin{array}{l}\text { Short symbol after } \\
\text { DIN } 18196\end{array}$ & $\begin{array}{l}\text { Consistence, } \\
\text { compactness } \\
\text { after DIN } \\
18121,18122\end{array}$ & $\begin{array}{l}\text { Specific } \\
\text { weight } \\
\left(\mathrm{kN} / \mathrm{m}^{3}\right)\end{array}$ & $\begin{array}{l}\text { Friction } \\
\text { angle }\left({ }^{\circ}\right)\end{array}$ & $\begin{array}{l}\text { Cohesion } \\
\left(\mathrm{kN} / \mathrm{m}^{2}\right)\end{array}$ & $\begin{array}{l}\text { Shear } \\
\text { strength } \\
\left(\mathrm{kN} / \mathrm{m}^{2}\right)\end{array}$ \\
\hline \multirow{2}{*}{$\begin{array}{l}\text { low plastic silt of loess } \\
\text { deposits, Ld } 3 \text { moderate } \\
\text { compact }\end{array}$} & \multirow{2}{*}{ UL } & supple & 20,0 & \multirow{2}{*}{27,5} & 0 & \multirow{2}{*}{$50-85$} \\
\hline & & Solid & 21,0 & & 5 & \\
\hline \multirow{2}{*}{$\begin{array}{l}\text { moderate plastic clays and } \\
\text { marls of periglacial cover } \\
\text { beds, Ld } 5 \text { compact }\end{array}$} & \multirow{2}{*}{$\mathrm{TM}$} & Supple & 19,0 & \multirow{2}{*}{22,5} & 0 & \multirow{2}{*}{ 85-190 } \\
\hline & & Solid & 20,5 & & 10 & \\
\hline \multirow{2}{*}{$\begin{array}{l}\text { sand-silt aggregate of } \\
\text { decomposed (calcareous) } \\
\text { sandstones, earth-moist }\end{array}$} & \multirow[t]{2}{*}{ SU } & $\begin{array}{l}\text { moderate } \\
\text { compact }\end{array}$ & 20,0 & 32,5 & - & $11-15$ \\
\hline & & Compact & 22,0 & 35,0 & - & $20-45$ \\
\hline \multirow{2}{*}{$\begin{array}{l}\text { moderate plastic marls of } \\
\text { Flysch bedrock } \\
\text { interbedding, Ld } 5 \text { compact }\end{array}$} & \multirow{2}{*}{$\mathrm{TM}$} & Supple & 19,0 & \multirow{2}{*}{22,5} & 0 & \multirow{2}{*}{$70-110$} \\
\hline & & Solid & 20,5 & & 10 & \\
\hline
\end{tabular}

and the proportion of the pore space with respect to specific weight according to DIN (1990; cf. [49]).

Due to the leaching of the calcareous cementation of the sandstones and the decomposition of the structure, the density decreases with depth. Sand-silt aggregates are almost free of clay and thus, cohesion is absent. Therefore, the stability is controlled by the friction angle and ranges in dependence of the bedding density between 32.5 und $35^{\circ}$ (Figure 4). A short-term enhancement of the stability can be due to moistening, which is defined as "apparent cohesion" (cf. $[36,49])$.

4.3.4. Moderate Plastic Marls of Flysch Bedrock Interbedding. The moderate plastic marls of Flysch bedrock interbedding are classified as "TM." The bedding is predominantly dense (Ld 5) and shear strength is within the range of 70$110 \mathrm{kN} / \mathrm{m}^{2}$ (Table 3), which is similar to the periglacial clays and marls. The moderate plastic marls of Flysch bedrock interbedding are stable under dry conditions up to slope gradients of $45^{\circ}$ and more (Figure 4). With increasing moistening and at the transition from solid to supple consistency, the strength of the periglacial redeposited clays and marls decreases fast. Thus, the soil mechanical stability is reduced to the friction angle in the case of supple conditions and at a total loss of cohesion (cf. [47, 49]).

\section{Discussion}

Taking into account the relation between the sedimentological structure and the soil mechanical properties, it is possible to derive a temporal sequence of morphodynamic processes for the study area. In this context, it is evident that the stability of slopes exceeding $27^{\circ}$ is controlled by several phases of slope formation (Figure 4). Investigations on the spatial distribution of slope surfaces and sediments in relation to the occurrence of recent landslides yield five phases in the study area.

Primarily, the first initial phase is constituted by a completely developed profile, recording the distribution of the sediments and the geomorphological setting before mass movements started (Figure 3). Periglacial cover beds and loess sediments have been deposited on top of the bedrock mainly during the Upper Pleniglacial to the Late Glacial period.

The Flysch sandstone is covered by a basal periglacial cover bed. In flat positions of the palaeo-surface, the Upper Pleniglacial loess has been deposited and partly modified by solifluction processes in its upper parts. After the loess deposition, the upper periglacial cover bed was formed in the Younger Dryas $[20,21]$. It has a wide spatial distribution in the study area.

During the second phase of slope formation (Holocene), a first sliding process occurs. In the course of the process, the permeable loess deposits slide on the top of the basal periglacial cover beds, which mainly consist of impermeable clays and marls. Figure 5(a) represents the scar of a landslide, corresponding to the second stage, which took place in 1996 in the Hagenbach Valley (eastern Vienna forest).

Subsequent to the sliding of the loess layers, a transition to the third phase (Holocene) is initiated, which corresponds to an erosional phase in the sequence. The downwash of the basal clays and marls, uncovering the solid bedrock, has to be regarded as the main aspect of this phase (Figure 5(b)).

The erosional processes, with respect to the uncovering of the bedrock, leads to the forth phase (Holocene), the decomposition phase (Figure 5(c)). Due to the removal of the basal periglacial cover bed, infiltration of water enriched by humic acids can take place and decompose the Flysch sandstones "Mürbsandstein." During this process, the latter are affected by a fast and profound weathering. The 


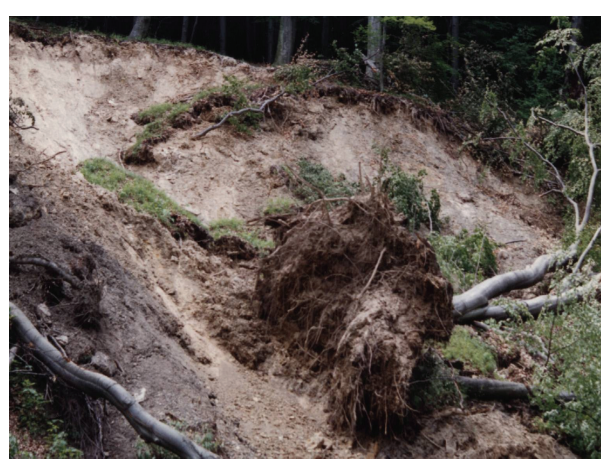

(a)

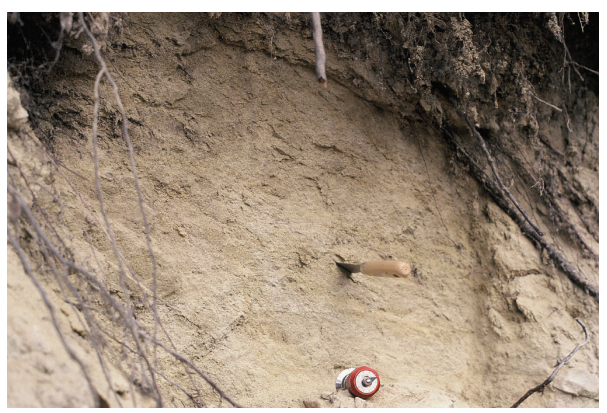

(c)

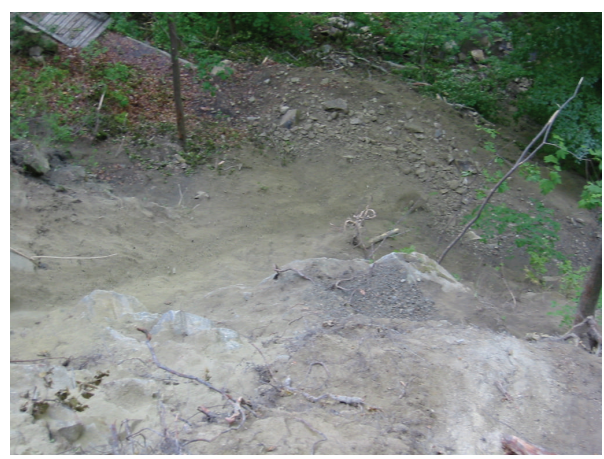

(b)

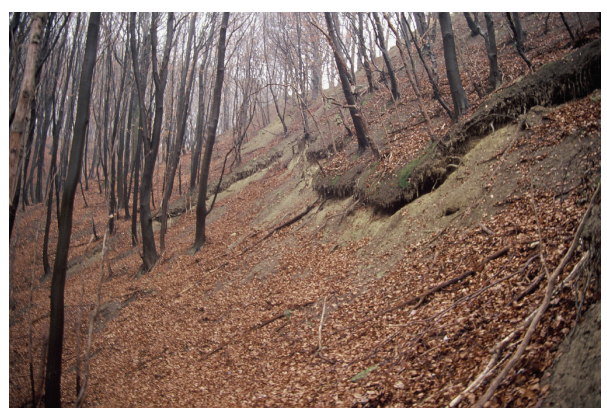

(d)

FIGURE 5: Landscape formation phases 2-5. First sliding phase (a): sliding of the loess surface formation on top of basal clays and marls. The figure shows the scar of landslide in 1996 in the northern Vienna Forest area. Erosional phase (b): subsequent to the sliding of loess surface formations and the erosion of landslide relics, the downwash of the basal clays and marls starts, uncovering the bedrock. Weathering phase (c): in particular sandstones, notably in the calcareous sandstones ("Mürbsandstein"), a profound decomposition proceeds due to the influence of humidity. Second sliding phase (d): the decomposed sandstone stratum is affected by further slides after exceeding a "critical mass".

carbonatic cementation of the sandstones is dissolved in major parts of the bedrock, resulting in loose sand packets with solid remains of different sizes.

The fifth phase (Holocene) represents the second sliding phase (Figure $5(\mathrm{~d})$ ). The decomposed sandstone stratum is affected by further slides after exceeding a "critical mass." This process results in repeated uncovering of Flysch bedrock. Joint structures and bedding planes cause the formation of joint-bordered rock bodies of different size, which are predestinated to undergo rockfall processes.

Afterwards, the phases four and five can reoccur in alternating patterns and/or rockfalls start in the decomposed sandstone.

Slope stability calculations on the basis of the "infinite mechanical slide model" and under consideration of the soil mechanical characteristics (see Table 3 ) result additionally in differentiated slope stabiltiy values for the presented slope formation phases. For an exemplary landslide with a width of $30 \mathrm{~m}$, a length of $15 \mathrm{~m}$, and a depth of $3 \mathrm{~m}$ the slope stability $[\eta]$ was calculated related to the slope angle $\left[{ }^{\circ}\right]$, namely for the first and the second sliding phase as well as for the erosional phase. The slope stability calculation was carried out for the loess stratum under solid and supple conditions, for clays and marls under solid conditions, and for decomposed sandstones under compact and moderate compact layering (Figure 4). The calculation of the pore water pressure as well as for the hydrostatic pressure was performed as a careful assumption for a vertical height of the water table of $0.1 \mathrm{~m}$ above the slide plane with respect to results of the field survey (see Section 4.1).

Figure 4 reveals a tendency of increasing slope stability in correspondence to the progress of the slope formation phases. In the specific case the limit equilibrium $\eta=1$ is achieved in solid clays and marls at a slope of about $31^{\circ}$, in solid loess strata at $31.5^{\circ}$, and in compact decomposed sandstones at $35^{\circ}$. In supple loess strata $\left(27.5^{\circ}\right)$ as well as in moderate compact decomposed sandstones $\left(32.5^{\circ}\right)$ limit equilibrium is relatively lower. The slope stability calculations yield that after passing phases $1-5$, the stability of slopes is increased by $3-5$ degrees on average.

\section{Conclusion}

The distribution of Quaternary sediments and occurrence of dense bedded periglacial cover beds, or more exact, the basal periglacial cover beds, are responsible for the development of landslides in steep slopes in the study area. The discrepancy concerning permeability in loess influenced layers and the underlying basal cover beds, consisting mainly of fine material, is the controlling factor for initiating mass movements. 
The results clearly indicate that different stages of slope evolution are present in the study area. The slopes are determined by the occurrence of variable slope formation stages as described by five phases. There are only minor locations that show undisturbed conditions, most of the studied slopes are affected by landslides and rockfall. Exposed sandstone, due to intense decomposition, is predestined to translational slides as well as to rockfall processes. The specific stages of slope formation cause a distinct spatial distribution of Quaternary sediments and solid rock at the present land surface. The occurrence and distribution of the different slope formation phases affect the recent morphodynamics in the study area. In consequence, the influence of Quaternary landscape formation related to soil mechanical properties significantly influence slope stability conditions in the study area. We conclude that after passing phases $1-4$, the stability of the studied slopes is increased. This conclusion can be attributed to the specific soil mechanical properties of the potential sliding masses and sediments. Up to phase 5 , the critical slope is increased by 3 to 5 degrees (cf. Figure 4 ).

Therefore, the consideration of the system analyses on a chronological scale (cf. [14]) and the input of the attained knowledge may increase the quality of GIS-based landscape modelling, hazard mapping, and further process-orientated approaches in landscape research. Therefore, the relation of morphogenetical results and applied aspects is a promising approach for future research.

\section{Acknowledgments}

This study was supported by the Institute of Geography and Regional Research, University of Vienna. Special thanks are due to the Physiogeographical Laboratory there, Dr. Robert Peticzka and Christa Hermann. Eva Köttritsch provided valuable support during the field survey and Thomas Ivkovits contributed photographs.

\section{References}

[1] H. Leser, Landschaftsökologie, UTB für Wissenschaft, Ulmer, Stuttgart, Germany, 1997.

[2] F. Barnickel and M. Becht, "Regional historical analysis of natural hazards in the Alps-the HANG Project," Zeitschrift für Geomorphologie, vol. 138, pp. 27-36, 2005.

[3] B. Damm and B. Terhorst, "Quaternary slope formation and landslide susceptibility in the Flysch Zone of the Vienna Forest (Austria)," in Gemorphology for the Future, A. KellererPirklbauer, M. Keiler, C. Embleton-Hamann, and H. Stötter, Eds., pp. 89-96, Innsbruck University Press, Innsbruck, Austria, 2007.

[4] K. J. Gregory and D. E. Walling, Eds., Man and Environmental Processes: A Physical Geography Perspective, Studies in Physical Geography, Dawson Westview Press, Boulder, Colo, USA, 1979.

[5] A. Semmel, "The importance of loess in the interpretation of geomorphological processes and for dating in the Federal Republic of Germany," in Landforms and Landform Evolution in West Germany, Catena, supplement 15, pp. 179-188, Catena, Cremlingen, Germany, 1989.
[6] A. Semmel, "The historic-genetic approach in applied geomorphology," Zeitschrift für Geomorphologie, vol. 40, pp. 289303, 1996.

[7] H. Leser, "Pedologisch-sedimentologische Untersuchungen als geomorphologische Methode," Forschungen und Fortschritte, vol. 40, pp. 296-300, 1996.

[8] B. Terhorst, "Mass movements of various ages on the Swabian Jurassic escarpment: geomorphologic processes and their causes," Zeitschrift für Geomorphologie, vol. 125, pp. 65-87, 2001.

[9] H.-R. Bork and A. Lang, "Quantification of past soil erosion and land use/land cover changes in Germany," in Long Term Hillslope and Fluvial System Modelling, vol. 101 of Lecture Notes in Earth Sciences, pp. 231-239, Springer, Berlin, Germany, 2003.

[10] K. Heine and H.-P. Niller, "Human and climate impacts on the Holocene landscape development in southern Germany," Geographia Polonica, vol. 76, pp. 109-122, 2003.

[11] T. Heckmann, F. Haas, V. Wichmann, and D. Morche, "Sediment budget and morphodynamics of an alpine talus cone on different timescales," Zeitschrift für Geomorphologie. In press.

[12] B. Neuhäuser and B. Terhorst, "Landslide susceptibility assessment using "weights-of-evidence" applied to a study area at the Jurassic escarpment (SW-Germany)," Geomorphology, vol. 86, no. 1-2, pp. 12-24, 2007.

[13] B. Damm and J. Hagedorn, "Holocene floodplain formation 12 in the southern Cape region, South Africa," Geomorphology. Accepted.

[14] S. W. Trimble, "Denudation studies: can we assume stream steady state?" Science, vol. 278, no. 4194, pp. 1207-1208, 1975.

[15] W. B. Bull, Geomorphic Responses to Climatic Change, Oxford University Press, New York, NY, USA, 1991.

[16] P. W. Birkeland, R. R. Shroba, S. F. Burns, A. B. Price, and P. J. Tonkin, "Integrating soils and geomorphology in mountains-an example from the Front Range of Colorado," Geomorphology, vol. 55, no. 1-4, pp. 329-344, 2003.

[17] B. Damm, "Geschiebe führende und murfähige Wildbäche in Mittelgebirgsräumen," Interpraevent, vol. 10, no. 3, pp. VII/61-VII/72, 2004.

[18] R. Kreja and B. Terhorst, "Naturgefahren in einem Baugebiet bei Öschingen an der Schwäbischen Alb: GIS-gestützte Ermittlung rutschungsgefährdeter Gebiete am Schönberger Kapf bei Öschingen," Die Erde, vol. 136/4, pp. 397-414, 2005.

[19] D. C. Miller, P. W. Birkeland, and D. T. Rodbell, "Evidence for Holocene stability of steep slopes, Northern Peruvian Andes, based on Soils and Radiocarbon dates.," Catena, vol. 20, pp. $1-12,1993$.

[20] A. Semmel, Studien über den Verlauf jungpleistozäner Formung in Hessen, Frankfurter Geographische Hefte 45, W. Kramer, Frankfurt am Main, Germany, 1968.

[21] B. Terhorst, "Soil distribution and periglacial cover beds in the Jurassic cuesta scarp in SW-Germany," Catena, vol. 71, pp. 467-476, 2007.

[22] Ad-Hoc-Arbeitsgruppe Boden, Bodenkundliche Kartieranleitung, E. Schweizerbart'sche Verlagsbuchhandlung, Hannover, Germany, 2005.

[23] D. Van Husen, "Massenbewegungen und Lockergesteinsanhäufungen in Abhängigkeit der würmzeitlichen Gletscherentwicklung am Beispiel des Trauntales (Oberösterreich).," Interpraevent, pp. 149-157, 1980.

[24] A. Semmel, Grundzüge der Bodengeographie, Teubner Studienbücher, Stuttgart, Germany, 1993. 
[25] W. Schilling and H. Wiefel, "Jungpleistozäne Periglazialbildungen und ihre regionale Differenzierung in einigen Teilen Thüringens und des Harzes," Geologie, vol. 11, pp. 428-460, 1962.

[26] R. Mailänder and H. Veit, "Periglacial cover-beds on the Swiss Plateau: indicators of soil, climate and landscape evolution during the Late Quaternary," Catena, vol. 45, no. 4, pp. 251272, 2001.

[27] D. Sauer, Genese, Verbreitung und Eigenschaften periglaziärer Lagen im Rheinischen Schiefergebirge-anhand von Beispielen aus Westerwald, Hunsrück und Eifel, Boden und Landschaft 36, Universität Gießen Inst. f. Bodenkde u. Bodenerhaltung, Gießen, Germany, 2002.

[28] A. Mahr, Lockerbraunerden und periglaziale Hangsedimente im Bayerischen Wald. Untersuchungen zu Paläoumwelt und Geomorphodynamik im Spätglazial und ihrem Einfluss auf die Pedogenese, Regensburger Geographische Schriften 30, Institut fur Geographie an der Universitat Regensburg Selbstverlag, Regensburg, Germany, 1998.

[29] H.-U. Schmincke, "Environmental impacts of the Lateglacial eruption of the Laacher See Volcano, $12.900 \mathrm{cal} \mathrm{BP,"} \mathrm{in} 150$ years of Neanderthal Discoveries. Terra Nostra 2006/2002, W. von Königswald and T. Litt, Eds., pp. 149-153, Springer, Bonn, Germany, 2006.

[30] T. Litt, H.-U. Schmincke, and B. Kromer, "Environmental response to climatic and volcanic events in central Europe during the Weichselian Lateglacial," Quaternary Science Reviews, vol. 22, no. 1, pp. 7-32, 2003.

[31] J. Völkel and M. Leopold, "Zur zeitlichen Einordnung der jüngsten periglazialen Aktivitätsphasen im Hangrelief zentraleuropäischer Mittelgebirge," Zeitschrift für Geomorphologie, vol. 45, pp. 273-294, 2001.

[32] V. Neubauer and V. Höck, "Aspects of geology in Austria and adjoining areas: introduction," Mitteilungen der Österreichischen Geologischen Gesellschaft, vol. 92, pp. 7-14, 2000.

[33] G. Götzinger, Neue Beobachtungen über Bodenbewegungen in der Flyschzone, Mitteilungen der Österreichischen Geographischen Gesellschaft 86, Verlag der Geographischen Gesellschaft, Wien, Germany, 1943.

[34] G. Wessely, Geologie der Österreichischen Bundesländer, Niederösterreich, Geologische Bundesanstalt, Wien, Germany, 2006.

[35] K. Knoblich, "Mechanische Gesetzmäßigkeiten beim Auftreten von Hangrutschungen," Zeitschrift für Geomorphologie, vol. 11, pp. 286-299, 1967.

[36] Q. Zaruba and V. Mencl, Landslides and Their Control, Elsevier Scientific, Amsterdam, The Netherlands, 1982.

[37] G. Gudehus, M. Goldschneider, and R. Lippomann, "Ingenieurgeologische und bodenmechanische Untersuchungen an Kriechhängen," in Ingenieurgeologische Probleme im Grenzbereich zwischen Locker- und Festgesteinen, K.-H. Heitfeld, Ed., pp. 316-335, Springer, Berlin, Germany, 1985.

[38] P. Gussmann, Numerische Verfahren. Grundbau-Taschenbuch, Ernst \& Sohn, Berlin, Germany, 5th edition, 1996.

[39] DIN, Erkundung und Untersuchung des Baugrundes, DINTaschenbuch 113, Beuth, Berlin, Germany, 2002.

[40] M. Pansu and J. Gautherou, Handbook of Soil Analysis: Mineralogical, Organic and Inorganic Methods, Springer, Berlin, Germany, 2006.

[41] B. Damm, "Gravitative Massenbewegungen in Südniedersachsen. Die Altmündener Wand-Analyse und Bewertung eines Rutschungsstandortes," Zeitschrift für Geomorphologie, vol. 138, pp. 189-209, 2005.
[42] DIN 4084, Baugrund, Gelände- und Böschungsbruchberechnungen, Deutscher Normenausschuss, Berlin, Germany, 1981.

[43] ÖNORM L1061 and B4412, Physikalische Bodenuntersuchungen; Bestimmung der Korngrößenverteilung des Mineralbodens, Österreichisches Normungsinstitut, Wien, Germany, 2002.

[44] K. Terzaghi, "Mechanism of landslides," Geological Society of America Bulletin, pp. 83-122, 1950.

[45] E. Bibus, B. Terhorst, and J. Kallinich, "Dating methods of mass movements in the MABIS-project," Zeitschrift für Geomorphologie, vol. 125, pp. 153-162, 2001.

[46] R. Peticzka, D. Riegler, and F. Ottner, "New results from profil "Stillfried B"," in New Aspects Concerning the Middle and Eastern European Upper Paleolithic - Methods, Chronology, Technology and Subsistence, Ch. Neugebauer, Ed., Mitteilungen der Prähistorischen Kommission Österreichische Akademie der Wissenschaften, Wien, Germany, 2007.

[47] F. Häfner, W. Fein, and U. Held, "Massenbewegungen im Saar-Nahe-Gebiet unter Berücksichtigung des Verwitterungsverhaltens der Pelite," in Ingenieurgeologische Probleme im Grenzbereich zwischen Locker- und Festgesteinen, K.-H. Heitfeld, Ed., pp. 297-307, Springer, Berlin, Germany, 1985.

[48] H.-J. Lang, J. Huder, and P. Amann, Bodenmechanik und Grundbau: Das Verhalten von Böden und Fels und die wichtigsten grundbaulichen Konzepte, Springer, Berlin, Germany, 1996.

[49] K. H. Hartge and R. Horn, Die physikalische Untersuchung von Böden, Ferdinand Enke, Stuttgart, Germany, 1992. 

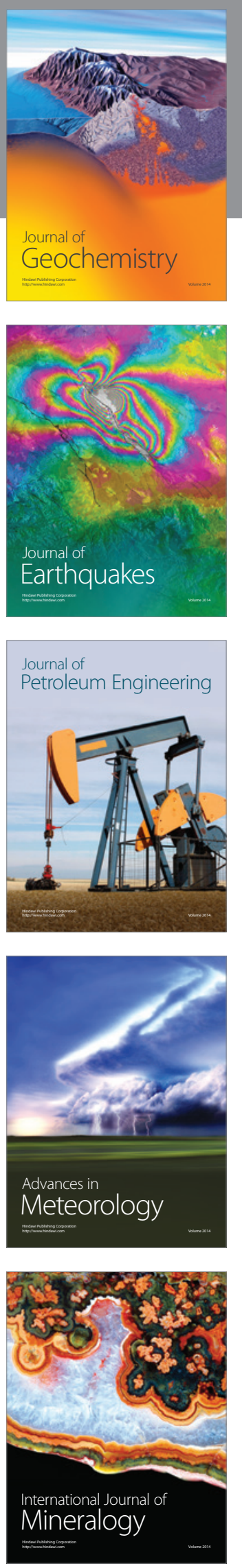
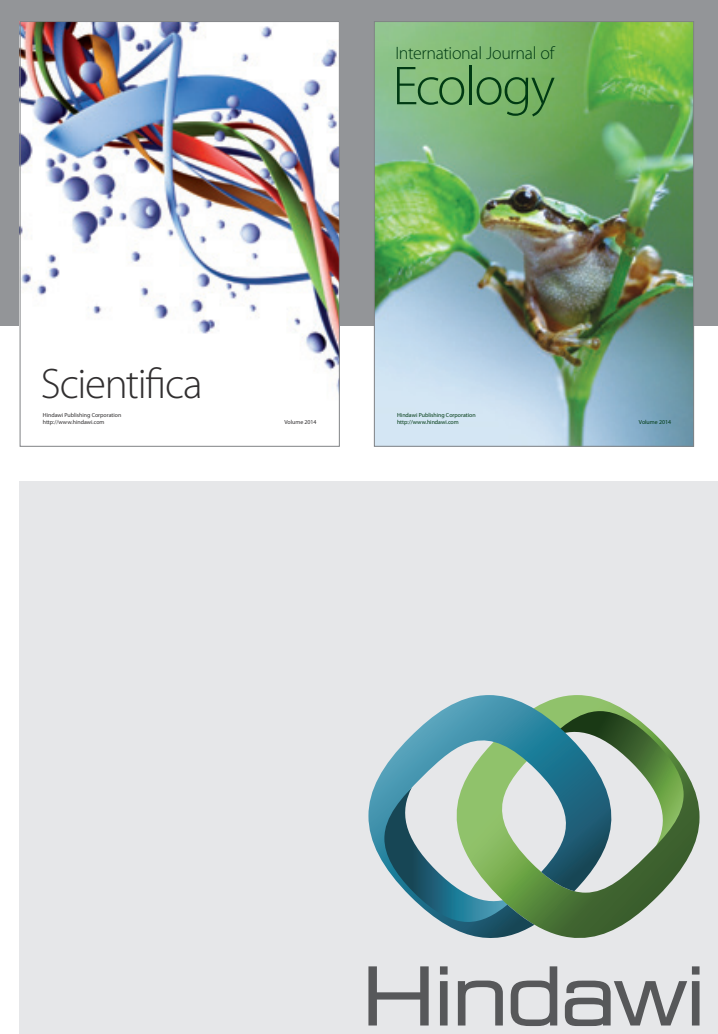

Submit your manuscripts at http://www.hindawi.com
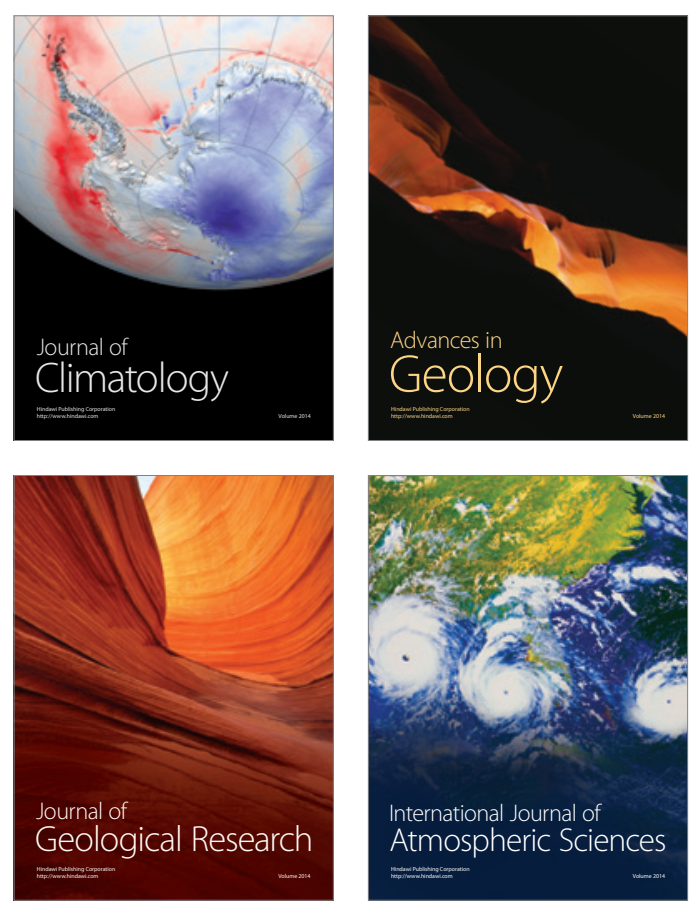
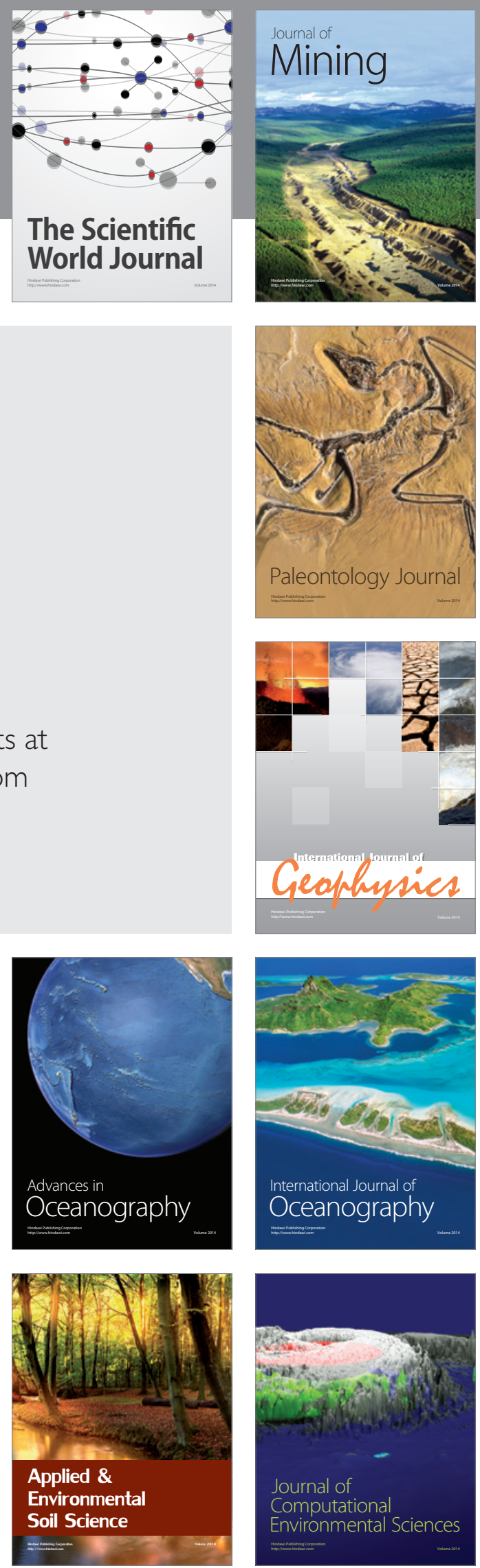